\title{
REASSESSMENT OF THE TYPE COLLECTIONS OF MASLOV'S SPECIES OF CORALLINALES (RHODOPHYTA). I. SPECIES ORIGINALLY ATTRIBUTED TO Lithophyllum AND Melobesia
}

\author{
Juan C. BRAGA ${ }^{1}$, Davide BASSI ${ }^{2}$, Elena \\ ZAKREVSKAYA ${ }^{3}$ and Eleonora PETROVNA \\ RADIONOVA
}

\author{
${ }^{1}$ Departamento de Estratigrafía y Paleontología. Universidad de Granada, Cam- \\ pus de Fuentenueva, E-18002 Granada, Spain. jbraga@ugr.es. \\ ${ }^{2}$ Dipartimento delle Risorse Naturali e Culturali. Università di Ferrara, Corso \\ Ercole I d'Este 32, I-44100 Ferrara, Italy. bsd@unife.it. \\ ${ }^{3}$ Vernadsky State Geological Museum RAS. Mokhovaya st. 11, bl. 2, 103009 \\ Moscow, Russia. zey@sgm.ru. \\ ${ }^{4}$ Geological Institute of Russian. Academy of Sciences, Pyzherskii pcr. 7, 109017 \\ Moscow, Russia.radionova@geo.tv-sign.ru.
}

Braga, J. C., Bassi, D., Zakrevskaya, E. \& Petrovna Radionova, E. 2005. Reassessment of the type collections of Maslov's species of Corallinales (Rhodophyta). I. Species originally attributed to Lithophyllum and Melobesia. [Re-evaluación de las colecciones tipo de especies de Corallinales (Rhodophyta) de Maslov. I. Especies atribuidas originalmente a Lithophyllum y Melobesia.] Revista Española de Paleontología, 20 (2), 207-224. ISSN 02136937.

\begin{abstract}
This paper is part of a wider project for reassessing Maslov's original collection of fossil calcareous algae with a modern taxonomic approach. Based on this collection, currently housed in the Geological Institute of the Russian Academy of Sciences of Moscow, Maslov described many taxa of calcareous algae of diverse ages from the former USSR in two monographs and several other papers from 1929 to 1973. As in other taxonomic publications from those decades, many of Maslov's new species of fossil coralline algae were distinguished by only a few characters of questionable taxonomic significance; in addition, most of his work was published in Russian with limited illustrations. This study deals in particular with Maslov's original preserved material of species attributed by him to the genera Lithophyllum and Melobesia (Corallinales, Rhodophyta). Our reassessment indicates that only the types of Lithophyllum duplex Maslov, and Hydrolithon corculumis (Maslov) comb. nov. (= Lithophyllum corculumis) show significant features justifying their use as species names in coralline algal taxonomy. The type of Lithophyllum microsporum Maslov is a gametangial plant that cannot be compared with the tetrasporangial plants used to delimit other coralline algal species within the Corallinaceae subfamily Lithophylloideae. Although they are validly published species names, the lack of significant characters in the preserved types prevents any confident placement of "Melobesia (Lithoporella) badjii", "Lithophyllum conocristatum", "L. dioscurensum", "M. (L.) karpatica" "L. (Tenarea?) lithothamnioides", "L. pavlovii”, "L. platticarpum", "L. premoluccense var. cretacicum", "L. senonicum", "L. translucidum" in any defined generic or suprageneric taxon within the Corallinales. The holotypes of " $M$. (L.) parasitica" and " $M$. (Dermatolithon) ucrainicum" were not found and only thin sections later illustrated by Maslov are available.
\end{abstract}

Key words: calcareous algae, taxonomy, Maslov's type collection, Corallinales, Rhodophyta.

\section{RESUMEN}

Este trabajo forma parte del proyecto de revisar con una perspectiva taxonómica moderna la colección de algas calcáreas fósiles de Maslov, depositada en el Instituto de Geología de la Academia de Ciencias de Rusia. Entre 1929 y 1973, Maslov describió muchos taxones de algas calcáreas fósiles, del Silúrico al Mioceno, de la antigua Unión Soviética, en dos amplias monografías y varios trabajos cortos. Como en otras publicaciones de aquellas décadas, muchos de sus nuevos taxones están basados en unos pocos caracteres de relevancia taxonómica discuti- 
ble. Además, Maslov publicó la mayor parte de su trabajo en ruso y con exiguas ilustraciones. En concreto, este trabajo trata sobre los tipos de las especies que Maslov atribuyó a los géneros Lithophyllum y Melobesia. Sólo los tipos de Lithophyllum duplex Maslov e Hydrolithon corculumis (Maslov) comb. nov. (=Lithophyllum corculumis) presentan suficientes caracteres para ser usados como nombres de especies en la taxomía de algas coralináceas. El tipo de Lithophyllum microsporum Maslov es una planta gametangial que no puede ser comparada con las plantas tetraesporangiales con las que se delimitan otras especies de Corallinaceae subfamilia Lithophylloideae. Aunque son nombres publicados válidamente, la ausencia de caracteres significativos en los tipos preservados impide asignar con seguridad "Melobesia (Lithoporella) badjii”, "Lithophyllum conocristatum", "L. dioscurensum”, “M. (L.) karpatica”, "L. (Tenarea?) lithothamnioides”, "L. pavlovii”, "L. platticarpum”, "L. premoluccense var. cretacicum", "L. senonicum”, "L. translucidum” a ningún género o subfamilia de Corallinales. Los holotipos "M. (L.) parasitica” y "M. (Dermatolithon) ucrainicum” no se han encontrado y sólo se han podido estudiar ejemplares ilustrados posteriormente por Maslov.

Palabras clave: algas calcáreas, taxonomía, colección de tipos de Maslov, Corallinales, Rhodophyta.

\section{INTRODUCTION}

This paper is part of an attempt by researchers on fossil coralline algae to locate and reassess, using a modern taxonomic approach, the original collections of taxa of this algal group described during the $19^{\text {th }}$ and first twothirds of the $20^{\text {th }}$ centuries (Rasser \& Piller, 1994; Aguirre et al., 1996; Braga \& Aguirre, 1998; Basso et al., 1998; Bassi et al., 2000; Woelkerling et al., 2002). Many species and genera of fossil coralline algae have been separated on the basis of only a few characters with slight or doubtful taxonomic significance. It is therefore imperative to restudy the original type material with new taxonomic perspectives to assess the status and circumscriptions of the taxa. As a consequence of the lack of reliable definitions, pre-existing names in the literature have not been commonly used by subsequent authors, who preferred to establish new species (and genera), further contributing to the large number of existing species names (Aguirre \& Braga, 2005).

The ignorance or misunderstanding of previously established taxa was especially considerable in the case of the species described by Maslov, who published most of his work in Russian monographs, printed in the former USSR. Maslov described a large number of new taxa of fossil calcareous algae, most belonging to the Corallinales, from rocks originating in Silurian to Miocene sedimentary successions from the vast geographic area of the former USSR, from 1929 to 1973 (Bassi et al., 2002).

The first aim of this work is to reassess the type collections of species originally placed in Lithophyllum or Melobesia (Maslov, 1956, 1962; Maslov in Krivin \& Maslov, 1962). No material has been found associated with two infraspecific names: Melobesia (Lithoporella) parasitica var. grandis Maslov, 1956 and Lithophyllum pavlovii var. irregularis Maslov, 1956. The second aim is to determine whether there is enough evidence in the preserved material to allow for placement of each taxon in a particular genus as delimited in a modern context. Assessing the relationships and the taxonomic status of species assignable to a particular genus is beyond the scope of the present study. This is the second contribution within the framework of the taxonomic revision of Maslov's collection, after the reassessment of the corallinalean genera established by this author (Bassi et al., 2005).

\section{MATERIAL AND METHODS}

Maslov's original material is represented by thin sections stored mostly in two boxes at the laboratory of palaeophycology in the Geological Institute of the Russian Academy of Sciences of Moscow. Examination of thin sections was carried out using light microscopy. Coralline-algal growth-form and anatomical terminology follows Woelkerling (1988), Braga et al. (1993), Woelkerling et al. (1993). Cell and conceptacle dimensions follow Chamberlain et al. (1988).

\section{SYSTEMATIC PALAEONTOLOGY}

\section{ORDER CORALLINALES Silva \& Johansen, 1986}

The Corallinales is the only Order of Rhodophyta in which most or all vegetative cell walls are impregnated with calcite (Silva \& Johansen, 1986). In the current taxonomy, three families with living representatives are recognized within the Corallinales: Corallinaceae, Hapalidiaceae and Sporolithaceae (Harvey et al., 2003) (Tab. 1). The Solenoporaceae Pia, 1927 is traditionally regarded as an extinct family of coralline-like red algae, morphologically similar to but simpler than modern Corallinales, ranging from the Cambrian to the Palaeogene. However, the type-species of Solenopora is a chaetetid sponge (Riding, 2004) and the group also contains fossils resembling cyanobacteria as well as red algae (Braga \& Riding, 2004). The families Corallinaceae and Hapalidiaceae include four and three subfamilies, respectively (Tab 1). In contrast to current concepts of these taxa, Maslov $(1956,1962)$ included in the family Corallinaceae all modern corallinales 
Family

Corallinaceae

Conceptacles uniporate, spores zonate

Corallinoideae

Mastophoroideae

Lithophylloideae

Metagoniolithoideae

Hapalidiaceae

Conceptacles multiporate, spores zonate

Melobesioideae

Austrolithoideae

Choreonematoideae
Main diagnostic characters

Cells of contiguous vegetative filaments linked by cell fusions; genicula composed of one tier of cells

Cells of contiguous vegetative filaments linked by cell fusions; genicula absent

Cells of contiguous vegetative filaments linked by secondary pit-connections; genicula (when present) composed of one or more tiers of cells

Unknown as fossils

Cells of contiguous vegetative filaments linked by cell fusions; genicula absent

Unknown as fossils

Unknown as fossils

Sporolithaceae

Calcified compartments, spores cruciate

Table 1. Main characters and character states diagnostic of the families and subfamilies of modern Corallinales (from Harvey et al., 2003).

and the 'solenoporaceans', and assigned all non-geniculate coralline red algae ('solenoporaceans' excluded) to the subfamily Melobesioideae (currently a subfamily within the Hapalidiaceae). Maslov (1956, 1962) included in Lythophyllum non-geniculate corallines with the following characters: encrusting, protuberant or branching plants; thallus consisting of cells well-arranged in rows; cell rows concentric in the "hypothallium" and parallel to the surface in the "perithallium"; conceptacle shape in vertical section like an inverted heart with a single pore at the top. He attributed to Melobesia Lamoroux, 1812 encrusting plants with one to two cell layers; "hypothallium" consisting of a single cell layer; and sporangial conceptacles, conical or hemispherical in shape, protruding on the thallus surface and possessing a single pore. In contrast to Maslov's concept, in a modern context, Lithophyllum includes non-geniculate Lithophylloideae (see Tab. 1) with dorsiventral or bilateral (but not isobilateral) internal organization and lacking haustoria (Woelkerling et al., 2002). Currently, Melobesia encompasses members of the subfamily Melobesioideae (Tab. 1), with a ventral unistratose layer of filaments and epithallial cells or multicellular filaments arising more or less perpendicularly from ventral-layer cells (dimerous construction) (Woelkerling, 1996).

\section{TAXA OF CERTAIN GENERIC PLACEMENTS}

The types of three of the species names established by Maslov (1962) and attributed by him to the genus Lithophyllum preserve vegetative and reproductive features that warrant their assignment to defined generic and suprage- neric entities within the order Corallinales (Tab. 2). Two of them also permit their use in taxonomic work on fossil coralline algae.

Family Corallinaceae Lamouroux, 1812

Subfamily Lithophylloideae Setchell, 1943

Genus Lithophyllum Philippi, 1837

\section{Lithophyllum duplex Maslov, 1962 Figs. 2a-c}

1962 Lithophyllum duplex Maslov, 82-83, pl. 21, figs. 1-3, textfig. 60.

1971 Lithophyllum duplex Maslov; Poignant, 1172, pl. 1.

1972 Lithophyllum duplex Maslov; Orzag-Sperber \& Poignant, 118.

1973 Lithophyllum duplex Masl.; Maslov, pl. 18, fig. 8.

1977 Lithophyllum duplex Maslov; Orszag-Sperber, Poignant \& Poisson, pl. 4, fig. 4.

? 1982 Lithophyllum cfr. duplex Maslov; Fravega \& Vannucci, fig. 10.

1985 Lithophyllum cf. duplex Maslov; Pisera, 105, pl. 20, fig. 4.

1988 Lithophyllum duplex Maslov; Studencki, 39, pl. 13, fig. $1-2$.

? 1989 Titanoderma duplex (Maslov, 1962) nov. comb.; Pisera \& Studencki, 202-203, pl. 11, figs. 6-7; pl. 12, fig. 3.

Holotype: Designated by Maslov (1962, p. 82), thin section 396, illustrated in pl. 21, figs. 2-3 and text-fig. 60 .

Age and locality: Badenian (Tortonian in Maslov, 1962), quarry of the Sakhkamen factory, village Medobory, Ukraine. 
Examination of the type collection: Only one thin section, labelled and numbered 396 (Fig. 1). A portion of the plant illustrated by Maslov (1962) is marked by an ink circle.

This is a plant with successive growth phases or several superimposed plants with encrusting ventral portions that give rise to lumpy protuberances (at least $3 \mathrm{~mm}$ high) bearing numerous buried conceptacles.

The thallus construction is dimerous in the ventral region and monomerous in the protuberances. Cells at the ventral primigenous filaments are 10-15 $\mu \mathrm{m}$ in length and 17-22 $\mu \mathrm{m}$ in height. Postigenous filaments arise perpendicularly to the primigenous ones and then expand and arch upwards, becoming radially arranged in the protuberances. Cell filaments are clearly distinct suggesting that cells of adjacent filaments are only connected by secondary pits. Cells are rectangular in section and their size ranges from 10 to $16 \mu \mathrm{m}$ in diameter and from 25 to 30 $\mu \mathrm{m}$ in length. Postigenous cells are slightly longer in the centre of protuberances. Lateral alignment of cells in adjacent filaments is well defined.

The numerous conceptacles (17), up $250 \mu \mathrm{m}$ in diameter and up $120 \mu \mathrm{m}$ in height, are uniporate and ellipsoidal in longitudinal section with a flat floor; they were sunken and became buried in the thallus. The pore canal is a funnel-like inverted cone. When new filaments cover the pore, the wider upper part of the pore remains as a small, second chamber on top of the conceptacle. These conceptacles could be either tetrasporangial or female/carposporangial.
Remarks: L. duplex has been illustrated only in a few cases although it is a typical component of rhodoliths in Mediterranean Neogene deposits (Fravega \& Vannucci, 1987) and has been mentioned in several reports (Mastrorilli, 1968; Orszag-Sperber \& Poignant, 1972; OrszagSperber et al., 1977; Fravega \& Vannucci, 1982; Fravega et al., 1984). The specimen illustrated by Fravega \& Vanucci (1982) was doubtfully assigned to L. duplex by the authors. The vegetative characters and the shape and size of the sporangial conceptacles of the depicted examples attributed by Pisera (1985), Studencki (1988) and Pisera \& Studencki (1989) to this species are similar to those of the holotype. The latter authors doubtfully transferred $L$. $d u$ plex to Titanoderma Nägeli, 1858. The transfer was based upon the presence of a "unistratose hypothallus" both in the holotype and in plants from the Miocene of Poland. However, unistratose ventral primigenous filaments are common in Lithophyllum plants with dimerous construction and, therefore, the transfer of L. duplex to Titanoder$m a$ is not justified. In addition, Titanoderma Nägeli can be considered a younger synonym of Lithophyllum according to some authors (Campbell \& Woelkerling, 1990; Woelkerling \& Campbell, 1992). Even if Titanoderma is maintained as a separate entity it can only be distinguished from

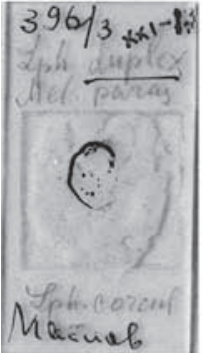

a

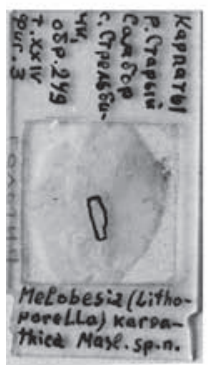

i

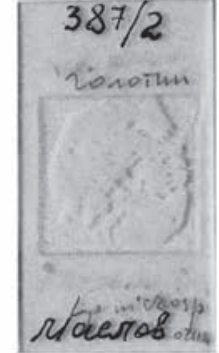

b

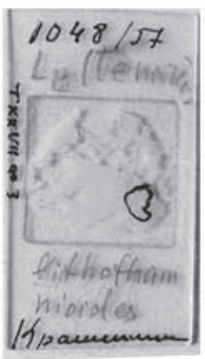

j

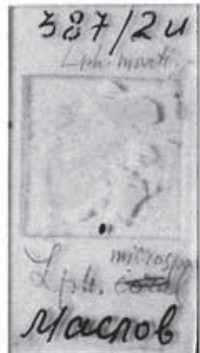

c

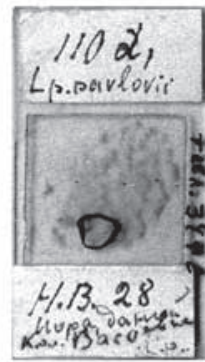

k

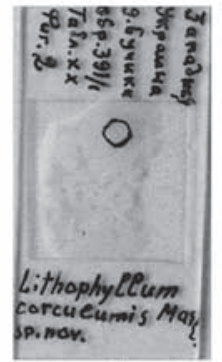

d

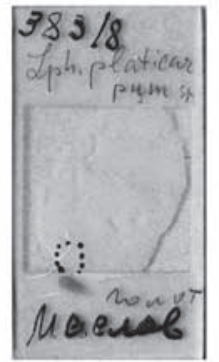

I

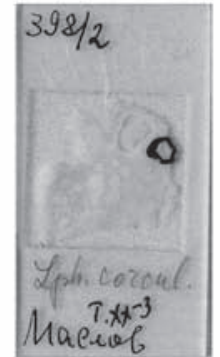

e

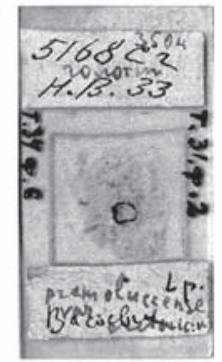

m

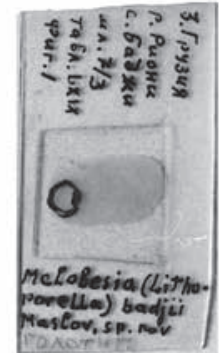

f

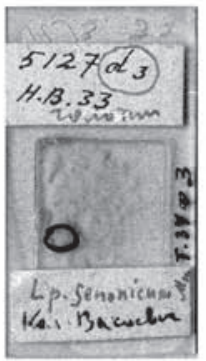

n

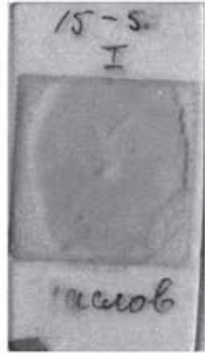

g

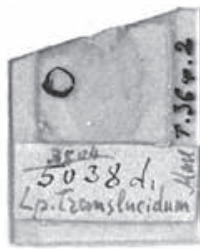

o

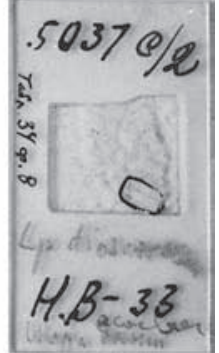

h

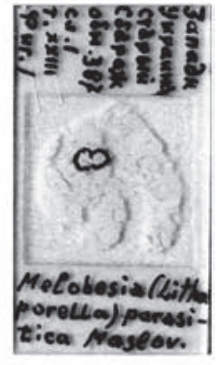

p

Figure 1. Thin sections of Maslov's collection; Geological Institute, Russian Academy of Sciences, Moscow. a, Lithophyllum duplex Maslov, 1962; 396, holotype. b, c, Lithophyllum microsporum Maslov, 1962; 387/2, 387/2u, holotype. d, e, Lithophyllum corculumis Maslov, 1962; 398/2, holotype. f, Melobesia (Lithoporella) badjii Maslov, 1956; 7/3, holotype. g, Lithophyllum conocristatum Maslov, 1962; 15/5, holotype. h, Lithophyllum dioscurensum Maslov, 1956; 5037c/2, holotype. i, Melobesia (Lithoporella) karpatica Maslov, 1962; 249, holotype. j, Lithophyllum (Tenarea?) lithothamnioides Maslov, 1962; 1048/57, lectotype. k, Lithophyllum pavlovii Maslov, 1956; 3504/110, holotype. 1, Lithophyllum platticarpum Maslov, 1962; 383/8, holotype. m, Lithophyllum premoluccense var. cretacicum Maslov, 1956; 5168, holotype. n, Lithophyllum senonicum Maslov, 1956; 5127, holotype. o, Lithophyllum translucidum Maslov, 1956; 3504/5038, holotype. p, Melobesia (Lithoporella) parasitica Maslov, 1956; 387. 
Lithophyllum by the occurrence of a bistratose margin with oblique, palisade hypothallial cells in juvenile and regenerating plants (Chamberlain, 1991). Neither the holotype nor the Middle Miocene Polish examples display any of these features. Instead they possess thick peripheral regions comprising postigenous filaments made up of many cells, similar to those in L. incrustans Philippi, the type species of the genus. If the preserved conceptacle were tetrasporangial, their features (shape, size, shape of pore canal, etc) might be diagnostic characters in separating L. duplex from other Lithophyllum species; however, a discussion of the relationship of $L$. duplex to other congeneric taxa is beyond the scope of this work.

\section{Lithophyllum microsporum Maslov, 1962} Figs. 2d-e

1962 Lithophyllum microsporum Maslov, 85-86, pl. 18, fig. 3, text-fig. 63.

? 1972 Lithophyllum microsporum; Orszag-Sperber \& Poignant, pl. 3, fig. 4 .

? 1977 Lithophyllum microsporum; Orszag-Sperber, Poignant \& Poisson, pl. 3, fig. 2; pl. 4, fig. 3.

? 1980 Lithophyllum microsporum Maslov; Vannucci, pl. 2, fig. 1.

? 1988 Lithophyllum microsporum Maslov; Studencki, 42, textfig. 8.

1996 Lithophyllum microsporum Maslov; Basso, Fravega \& Vannucci, 286-287, pl, 67, figs. 1-5 (holotype)

Holotype: Maslov (1962, p. 85) designated the sample 387/2 as the holotype. There are two thin sections with this numbering: $387 / 2$ and $387 / 2$ u (Fig. 1). The first one is labelled "holotype", probably by a curator of Maslov's collection but the plant illustrated by Maslov (1962: pl. 18, fig. 3) is in thin section 387/2u. The latter was studied and illustrated as the holotype of L. $\mathrm{mi}$ crosporum by Basso et al. (1996). The two thin sections contain plants with similar vegetative characters and were most probably cut from the same hand sample. They can therefore be considered as two preparations from the holotype sample. Thin section $387 / 2$, however, also contains specimens of coralline algae that are not conspecific with the ones in $387 / 2$ u.

Age and locality: Badenian (Tortonian in Maslov, 1962), village Staryj Sbarazh, western Ukraine.

Examination of the type material: The two thin sections (Fig.1) contain fragments of protuberances from one or several plants. Each fragment consists of a single system of dividing, fan-like cell filaments. Changes in the density (darkness) of micrite in the cell walls depict weak growth zonation. Well-defined cell walls separating adjacent filaments clearly indicate the absence of cell fusions and suggest that only secondary pits connect adjoining cells $(7-10 \mu \mathrm{m}$ in diameter and 16-20 $\mu \mathrm{m}$ in height).

The numerous preserved conceptacles are small $(70-86 \mu \mathrm{m}$ in diameter and 32-38 $\mu \mathrm{m}$ in height) and flat-elliptical in longitudinal section. The pore canal is large relative to the size of the conceptacle chamber and conical in shape. In several cases the chamber, together with the pore, is triangular in section. The size and shape of the conceptacle in the type of L. miscrosporum are typical of gametangial, particularly spermatangial, conceptacles of members of the subfamily Lithophylloideae.

Remarks: The vegetative features of the protuberance fragments in the holotype of L. microsporum are diagnostic of Lithophyllum (Lithophylloideae, Corallinaceae). The characters supposedly separating this from other Lithophyllum species are in fact features typical of gametangial plants and cannot be compared with sporangial plants used to delimit other species of the genus. Braga \& Aguirre (1995) and Basso et al. (1996) suggested that plants with the features of L. miscrosporum were gametangial specimens conspecific with Miocene sporangial plants attributed to L. viennotii Lemoine, 1929. Braga \& Aguirre (1995) considered L. viennotii (and consequently L. microsporum) a younger heterotypic synonym of Lithophyllum incrustans Philippi, 1837. In contrast, Basso et al. (1996) neotypified Lithophyllum racemus Lamarck and proposed $L$. viennotii (and L. microsporum) as one of its heterotypic synonyms. The plants attributed by different authors to $L$. microsporum and illustrated in the publications doubtfully (question mark) included in the synonym list correspond to gametangial Lithophyllum plants. These gametangial thalli, however, do not show diagnostic characters that would confidently warrant their placement in a definite Lithophyllum species.

\section{Subfamily Mastophoroideae Setchell, 1943} Genus Hydrolithon Foslie, 1909

\section{Hydrolithon corculumis (Maslov) comb. nov. Figs. 2f-h}

Basionym: Lithophyllum corculumis, Maslov, 1962, Fossil red algae of USSR and their connections with facies. Trudy Geologicheskogo Instituta Akademii Nauk SSSR, p. 80, pl. 20, figs. 1-3; pl. 21, fig. 2; pl. 27, fig. 2, text-fig. 57.

1973 Lithophyllum corculumis Maslov, pl. 18, figs. 9, 11.

1985 Lithophyllum corculumis Maslov; Pisera, 104, pl. 24, figs. 1-4.

non 1988 Lithophyllum corculumis Maslov; Studencki, 38-39, pl. 12 , fig. 4 .

Holotype: Designated by Maslov (1962, p. 80), thin section $398 / 2$, illustrated in pl. 20 , fig. 3 (in the plate caption the picture is wrongly attributed to thin section 392/2). The plant illustrated is marked by an ink circle.

Age and locality: Badenian (Tortonian in Maslov, 1962), village Derjunevka, south of Trembovli, western Ukraine.

Examination of the type collection: In addition to the thin section containing the holotype (Fig. 1) there are two other thin sec- 

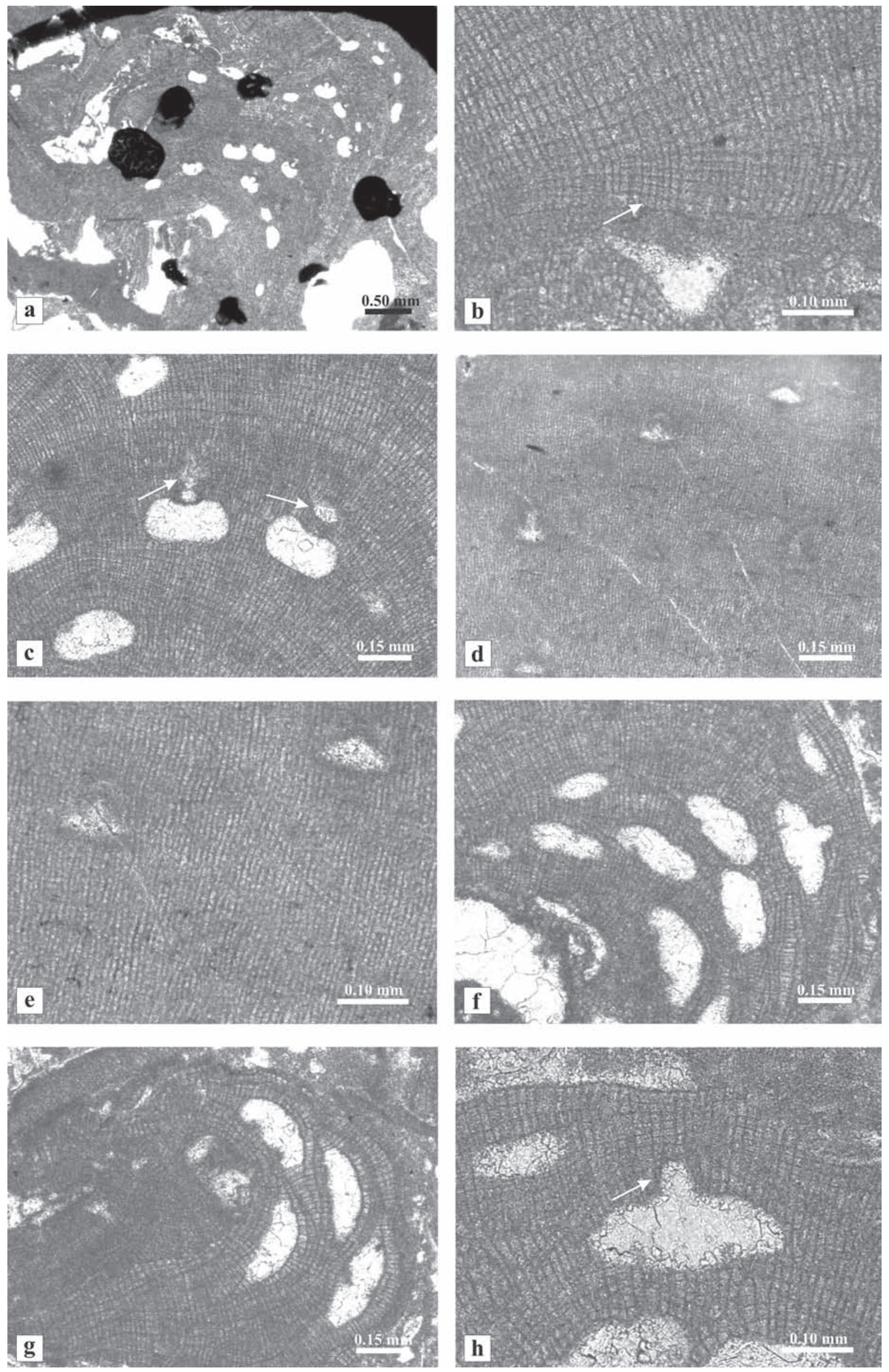
tions with plants included by Maslov (1962) in this species: 391/1 partly illustrated in pl. 20, fig 2, and 392/2 in pl. 20, fig. 1.

Plants are encrusting to warty. The thallus is dorsiventral and dimerous with cells in primigenous filaments similar to those in the postigenous ones, which arise perpendicular to the former. Cell fusions connecting adjacent postigenous filaments are common. Cells are irregular in shape and relatively large (10-15 x 10-16 $\mu \mathrm{m})$. Cell length increases at the side of conceptacles to adjust to the thickening of the thallus in areas of conceptacle development (Fig. 2f-h). Epithallial cells have not been recognized.

The numerous conceptacles (30) are uniporate with a lensshaped to trapezoidal section (up to $275 \mu \mathrm{m}$ in diameter and up to $100 \mu \mathrm{m}$ in height). Conceptacles protruded on the thallus surface and later became buried in the thallus. Pore canals are slightly conical. Cell filaments in the conceptacle roof around the pores are short, consisting of 3-4 cells, and parallel to the pore walls. These conceptacles can be interpreted as (tetra)sporangial or female/carposporangial.

Remarks: The occurrence of cell fusions in postigenous filaments in the holotype of $H$. corculumis precludes its inclusion in Lithophyllum or any other genus within the subfamily Lithophylloideae. The thick dimerous thallus construction combined with cell fusions supports placement in the Mastophoroideae since no dimerous melobesioids with thick thallus and buried conceptacles are known. The presence of short cell filaments parallel to the walls of the pore canal in the conceptacle roof indicates that it can be included in Hydrolithon (Penrose \& Woelkerling, 1992; Braga et al., 1993). The plant attributed to this species and illustrated by Studencki (1988) shows well-defined, continuous cell walls separating adjacent filaments, indicating no cell fusions. This suggests that the Studencki plant belongs to a Lithophyllum species and therefore cannot be assigned to $H$. corculumis.

\section{TAXA OF UNCERTAIN GENERIC PLACEMENT}

The types of the following species names established by Maslov $(1956,1962)$ do not preserve enough significant characters to be confidently placed in generic and suprageneric taxa within the Corallinales (Tab. 2). We recommend not using any of these names unless: (1) a well-characterized coralline species is delimited in fossil material from the same age and locality from which the type of a name derives, and (2) it can be shown that this

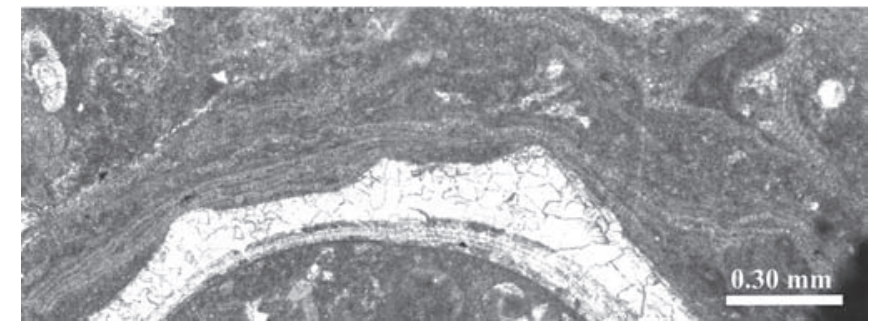

Figure 3. Melobesia (Lithoporella) badjii Maslov, 1956. Many superimposed thin encrusting plants or superimposed applanate branches of one or several plants with dorsiventral dimerous thalli.

type belongs to the well-characterized species to which, therefore, the name can be applied.

\section{Melobesia (Lithoporella) badjii Maslov, 1956} Fig. 3

1956 Melobesia (Lithoporella) badjii Maslov, 166, pl. 69, figs. 1-3; text-fig. 86.

1962 Melobesia (Lithoporella) badjii Maslov; Maslov, 98-99, text-fig. 77.

Holotype: Designated by Maslov (1956, p. 166), thin section $3504 / 7 / 3$, illustrated in pl. 69 , figs. $1-3$; text-fig. 86.

Age and locality: Miocene ("Chokrakian"), Rioni river, village Badzhi (Georgia).

Description: The remaining thin section (numbered 7/3) contains the plant or plants described and illustrated by Maslov (1962: pl. 69, fig. 1) (Fig. 1). There are many superimposed thin, encrusting plants or superimposed applanate banches of one or several plants ( $230 \mu \mathrm{m}$ thick) that grew on a bioclast. The original calcite in the cell walls seems to be recrystallized and the plants are poorly preserved. Thalli are dorsiventral with dimerous construction. Cells in primigenous filaments are connected by cell fusions. Small flattened cells locally preserved on top of the primigenous ones can be interpreted as epithallial cells that formed the very short postigenous filaments. No conceptacles can be recognised.

Remarks: The occurrence of cell fusions in the thalli with dimerous construction would suggest an affinity of $M$. (L.)

Figure 2. a-c: Lithophyllum duplex Maslov, 1962; a, longitudinal to oblique section of the lumpy protuberance bearing numerous conceptales; b, primigenous ventral cell filaments (well- defined cell walls separating adjacent filaments suggest the absence of cell fusions; arrow); c, slightly oblique sections of uniporate conceptacles from Fig. 2a showing the funnel-like, inverted cone, pore canal (arrows). d-e: Lithophyllum microsporum Maslov, 1962; d, detail of a protuberance bearing several small conceptacles; e, close-up of Fig. 2d showing the well-defined cell walls between adjacent filaments which suggest the absence of cells fusions; note the small, spermatangial conceptacles. f-h: Hydrolithon corculumis (Maslov) comb. nov; $\mathbf{f}, \mathbf{g}$, sections of lumpy protuberances with numerous buried conceptacles; $\mathbf{h}$, close-up of uniporate conceptacle on the right side in figure $2 \mathrm{f}$ showing the slightly conical pore canal surrounded by short cell filaments parallel to the pore wall (arrow). 
badjii with genera in the Corallinaceae subfamily Mastophoroideae or the Hapalidiaceae subfamily Melobesioideae, which show similar vegetative features. In the Mastophoroideae, species in genera such as Hydrolithon Foslie, 1909, Lithoporella Foslie, 1909, Mastophora Decaisne, 1842 and Pneophyllum Kützing, 1843 have dimerous thalli 2-3 cells thick and uniporate sporangial conceptacles (Woelkerling, 1996). The genus Melobesia Lamoroux, 1812 (Melobesioideae) has similar vegetative features with multiporate sporangial conceptacles (Woelkerling, 1988, 1996). The absence of any reproductive structure in the plants in the type of $M$. (L.) badjii prevents any reliable assignment of the species to precise generic and suprageneric taxa within the Corallinales (Tab. 2).

\section{Lithophyllum conocristatum Maslov, 1962} Figs. 4a-b

1962 Lithophyllum conocristatum Maslov in Krivin \& Maslov, 69-70, text-fig. 5 .
Holotype: Designated by Maslov in Krivin \& Maslov (1962, p. 70 ), thin section $15 / 59$ (now labelled as 15/5).

Age and locality: Danian, Zayachusskaya formation, Eastern Carpathians, Rakhovsky district, village Kobyletzskaya polyana, Shopurka river valley, Ukraine.

Examination of the type material: The only remaining type material is the holotype thin section (Fig. 1). It contains two branches of a plant or two plants growing one over the other. The thallus is encrusting, dorsiventral and monomerous. Cell filaments run parallel to the substrate forming a plumose ventral core and curve upwards to become perpendicular to the dorsal surface. Cell fusions are frequent in adjacent filaments. Cells are generally small, slightly larger in the core than in the peripheral region (4-6 $\mu \mathrm{m}$ in diameter and 6-10 $\mu \mathrm{m}$ in height).

The only preserved conceptacle protrudes conspicuously on the thallus surface. It is uniporate and trapezoidal in section, $330 \mu \mathrm{m}$ in diameter and $130 \mu \mathrm{m}$ in height. The pore canal is cylindrical (62 $\mu \mathrm{m}$ in diameter) to slightly conical and relatively long $(143 \mu \mathrm{m})$. The filaments of the conceptacle roof around the pore are arranged in fans oblique to the pore walls. There

\section{Maslov's disposition \\ Family Corallinaceae \\ Subfamily Melobesiae}

Lithophyllum duplex Maslov, 1962

Lithophyllum corculumis Maslov, 1962

Lithophyllum microsporum Maslov, 1962

Lithophyllum premoluccense var. cretacicum Maslov, 1956

Lithophyllum platticarpum Maslov, 1962

Lithophyllum dioscurensum Maslov, 1956

Lithophyllum conocristatum Maslov in Krivin and Maslov, 1962

Lithophyllum (Tenarea?) lithothamnioides Maslov, 1962

Lithophyllum pavlovii Maslov, 1956

Lithophyllum senonicum Maslov, 1956

Lithophyllum translucidum Maslov, 1956

Melobesia (Lithoporella) badjii Maslov, 1956

Melobesia (Lithoporella) karpatica Maslov, 1962

Melobesia (Lithoporella) parasitica Maslov, 1956

\section{Disposition proposed} in this paper

Order CORALLINALES

Silva \& Johansen, 1986

Family Corallinaceae

Lamouroux, 1812

Lithophyllum duplex Maslov

Hydrolithon corculumis (Maslov) comb. nov.

Lithophylloid

Lithophylloid

Mastophoroid

Melobesioid

Unknown affinities

Unknown affinities

Unknown affinities

Unknown affinities

Unknown affinities

Unknown affinities

Unknown affinities

Unknown affinities
Subfamily Lithophylloideae Setchell, 1943

Subfamily Mastophoroideae Setchell, 1943

Table 2. Summary of the proposed taxonomic disposition of the studied species. 
are no remaining characters to aid in discerning whether it was a gametangial or a sporangial conceptacle.

Remarks: The uncertain nature of the preserved conceptacle prevents the assignment of the type of $L$. conocristatum to a precise family and subfamily within the Corallinales (Tab. 2). If it were a gametangial conceptacle, its size would suggest that the type belongs to a genus of Melobesioideae within the family Hapalidiaceae (see Harvey et al., 2003), such as Lithothamnion or Phymatolithon. If the conceptacle were a sporangial one, the species would have to be included in the Corallinaceae subfamily Mastophoroideae, most probably in the genus Spongites.

\section{Lithophyllum dioscurensum Maslov, 1956} Figs. 4c-d

1956 Lithophyllum dioscurensum Maslov, 120, pl. 34, fig. 8, text-fig. 50.

1962 Lithophyllum dioscurensum Maslov; Maslov, 81-82, textfig. 59.

Holotype: Designated by Maslov (1956, p. 129), thin section $3504 / 5037$, now numbered $5037 \mathrm{c} / 2$.

Age and locality: Danian?, Iora river basin, Georgia.

Examination of the type material: The thin section (Fig. 1) contains a large fragment of a long protuberance, about $2 \mathrm{~mm}$ long and $0.5 \mathrm{~mm}$ in diameter. It consists of a single system of radiating and dividing cell filaments, arranged in a fan-like pattern. The primary cell walls of cells in adjacent filaments are laterally well aligned, generating the coaxial structure of the protuberance core. Cells are generally small (7-10 $\mu \mathrm{m} \times 12.5-20 \mu \mathrm{m})$ and slightly longer in the centre of the coaxial core. Cell fusions are common, especially in the outer region of the protuberance.

Two structures preserved in the outer region of the plant can be interpreted as the remains of the early developmental stages of two multiporate conceptacles, up to $150 \mu \mathrm{m}$ in diameter and $40 \mu \mathrm{m}$ in height (Fig. 4c-d). The poorly defined long cells in these structures probably reflect cell elongation of conceptacle primordia, which takes place within the thallus in many coralline species (Adey, 1965; Woelkerling, 1988).

Remarks: The co-occurrence of cell fusions and multiporate conceptacles in the holotype of $L$. dioscurensum indicates that the plant belongs to the Hapalidiaceae subfamily Melobesioideae. The absence of further diagnostic characters prevents any confident assignment of the species to a definite genus within this subfamily (Tabs. 1, 2).

\section{Melobesia (Lithoporella) karpatica Maslov, 1962}

Figs. $4 \mathrm{e}-\mathrm{f}$

1962 Melobesia (Lithoporella) karpatica Maslov, 99-100, pl. 24, fig. 3, text-fig. 78 .
Holotype: Designated by Maslov (1962, p.100), thin section 249, illustrated in pl. 24, fig. 3, text-fig. 78.

Age and locality: Palaeogene, village Strelbichi, pre-Carpathians.

Examination of the type material: The analysed thin section contains the specimen described and illustrated by Maslov (1962, pl. 24, fig. 3) (Fig. 1). It is a broken, thin encrusting thallus, 5 $\mathrm{mm}$ long and $0.12 \mathrm{~mm}$ thick, cut with changing orientation in the section. The thallus is dorsiventral and dimerous. Primigenous cell filaments are composed of palisade cells (17-18 $\mu \mathrm{m}$ in diameter and 22-26 $\mu \mathrm{m}$ in length) connected by cell fusions. The short postigenous cell filaments consist of several cells (13-17 $\mu \mathrm{m}$ in diameter and $17-20 \mu \mathrm{m}$ in length) connected by cell fusions. The outer thallus surface is badly preserved and no possible epithallial cells can be recognised. No reproductive structures can be observed in the holotype.

Remarks: The vegetative characters (fusions of cells of adjacent filaments) of the holotype suggest an affinity of $M$. (L.) karpatica with genera in the Corallinaceae subfamily Mastophoroideae or in the Hapalidiaceae subfamily Melobesioideae. The absence of any reproductive structures in the plants in the type of $M$. (L.) karpatica prevents any reliable assignment of the species to particular generic and suprageneric taxa within the Corallinales (Tab. 2).

\section{Lithophyllum (Tenarea?) lithothamnioides Maslov, 1962 Figs. 5a-b}

1962 Lithophyllum (Tenarea?) lithothamnioides Maslov, 96-97, pl. 27, fig. 3, text-fig. 75 .

? 1988 Lithophyllum lithothamnioides Maslov; Studencki, 40, pl. 7, fig. 3; pl. 14, figs. 1-2.

? 1989 Lithophyllum lithothamnioides Maslov; Pisera \& Studencki, 201, pl. 11, fig. 1.

Lectotype: Maslov (1962, p. 96) designated the thin section 1047 as the 'holotype' but all the illustrations he provided of the species correspond to thin section 1048. The latter is not an additional preparation from the same hand sample but from a different one. According to ICBN Article 9.13 (Greuter et al., 2000), "The holotype (or lectotype) of a name of a species or infraspecific taxon of fossil plants is the specimen (or one of the specimens) on which the validating illustrations are based. When,... in the protologue of a name of a new taxon... a type specimen is indicated but not identified among the validating illustrations a lectotype must be designated from among the specimens illustrated...". In accordance with this article, we herein select as the lectotype the plant in thin section 1048 (Fig. 1; Fig. 5a-b), which is the only one illustrated by Maslov (1962: pl. 27, fig. 3 and text-fig. 75) when he established Lithophyllum (Tenarea?) lithothamnioides. It is a branching, laminar plant, a portion of which is marked with an ink circle by the Russian author (Fig. 5a).

Age and location: Badenian (Tortonian in Maslov, 1962), Tarkhankut peninsula, Crimea. 

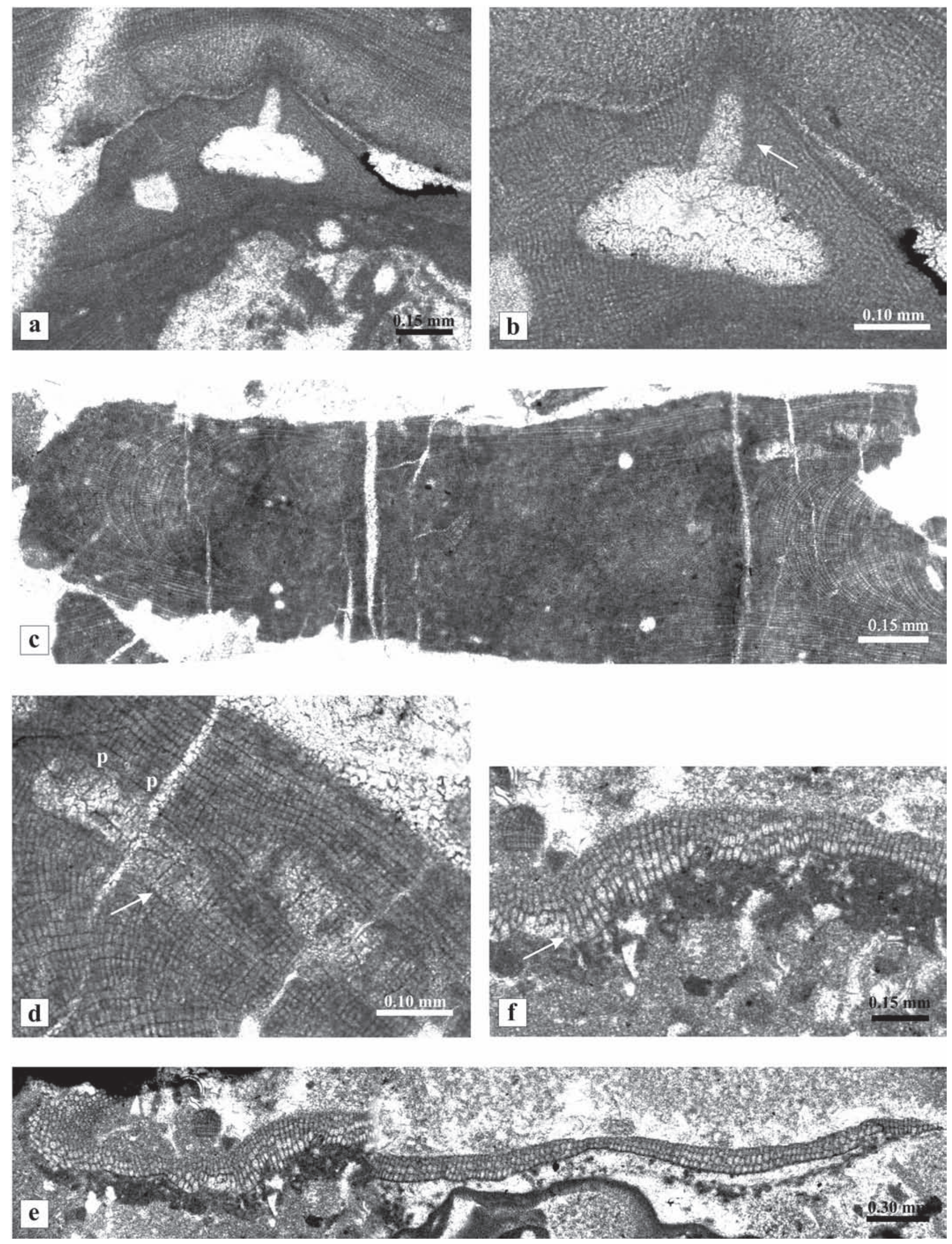
Examination of the type material: There are two thin sections from Maslov's original collection of L. (T.?) lithothamnioides: the one containing the lectotype designated here and the one (invalidly) designated as the 'holotype' (Fig. 1). The two thin sections contain contorted and branching laminar plants several millimetres in length and about $0.15 \mathrm{~mm}$ in thickness, which grew on a soft, fine-grained substrate. The thalli are monomerous with bilateral growth: a single system of radiating filaments that grew and curved outwards to both sides, although one direction may be preferential in portions of the thalli. Due to contortion, branching and random orientation of the different plants in the fine-grained matrix of the rock, it is difficult to recognise the polarity of plant growth. Cells of adjacent filaments are frequently fused; cell walls are not laterally well aligned. Cells in the core of the thallus are long and become shorter towards the outer surfaces (7-10 $\mu \mathrm{m}$ in diameter and 16-20 $\mu \mathrm{m}$ in height). Flat cells that can be interpreted as epithallial cells (10-20 x 5 $\mu \mathrm{m})$ are locally preserved at the filament tips, forming a laterally continuous layer. They have lighter calcite walls, a feature common in present-day and fossil epithallial cells. These rows of epithallial cells were interpreted by Maslov (1962) as thin crusts of Melobesia parasitica Maslov (see below). However, as stated by Studencki (1988), each flat cell is the terminal cell of a subtending filament in the thallus.

No conceptacles were observed in the preserved type material.

Remarks: Maslov (1962) doubtfully attributed this species to Tenarea Bory, 1832, as a subgenus of Lithophyllum Phillipi, 1837, probably due to the bilateral orientation of the cell filaments in the thalli. As pointed out by Woelkerling (1988), Tenarea has undergone marked changes in its circumscription since its description but according to a modern revision of the type species (Woelkerling et al., 1985), Tenarea is readily differentiated from other coralline algal genera. It has an isobilateral organisation with two central rows of primigenous filaments of palisade cells that is unique among the known coralline algae. As in other lithophylloid genera, cells of adjacent filaments in Tenarea are joined by secondary pits with no cell fusions.

The occurrence of cell fusions in the type of lithothamnioides suggests that it belongs either to the subfamily Melobesioideae in the family Hapalidiaceae or to the subfamily Mastophoroideae in the Corallinaceae. The lack of sporangial conceptacles and other diagnostic characters, however, prevents any confident attribution of the species to any taxon at the generic or subfamily levels (Tab. 2). The plants illustrated by Studencki (1988) in pl. 7 fig. 3 (bottom) and pl. 14 fig 1 might be conspecific with the lithothamnioides lectotype, but the lack of diagnostic features prevents any confident comparison. As stated by Studencki (1988, p. 40), it is very difficult to recognise whether the conceptacle in the plant in pl. 14 fig. 2 in Studencki (1988) occurs within a thallus similar to the lithothamnioides lectotype or whether it belongs to a different plant. In addition, no features distinctive of lithothamnioides can be observed in the thallus with a possible conceptacle illustrated (but not described) by Pisera \& Studencki (1989, pl. 11, fig. 1). The specific circumscription of these latter two specimens remains uncertain and consequently no conceptacles have been confidently recognised in plants attributable to "L. lithothamnioides" Maslov.

\section{Lithophyllum pavlovii Maslov, 1956}

Fig. 5c

1956 Lithophyllum Pavlovii Maslov, 120-121, pl. 34, figs. 2 and 4, text-fig. 51 .

1962 Lithophyllum pavlovii Maslov; Maslov, 86-87, text-fig. 64.

Holotype: Designated by Maslov (1956, p. 120), thin section 3504/110 (Fig. 1), illustrated in pl. 34, figs. 2 and 4 and textfig. 51. In addition to the illustrated specimen, there are other coralline algal fragments in the thin section that might be conspecific.

Age and locality: Danian?, Iora river basin, Georgia.

Examination of the type material: The plant illustrated by Maslov is a small, isolated fragment $(1.5 \times 0.5 \mathrm{~mm}$ in size $)$ that consists of a single system of radiating and dividing, fan-like arranged filaments. It is difficult to determine whether it represents a branch fragment of a nongeniculate or an intergenicula segment of a geniculate coralline.

Primary cell walls are laterally well-aligned in the core of the thallus, generating coaxial organisation; the cells are 5-10 $\mu \mathrm{m}$ in diameter and 22-25 $\mu \mathrm{m}$ in height. Cell filaments arch outwards to become perpendicular to the outer surface. Fusions of cells of adjoining filaments can be observed in longitudinal and transverse sections of filaments. No conceptacles are observed.

Remarks: The lack of diagnostic characters in the type of the species prevents its assignment to known genera or subfamilies within the Corallinales (Tab. 2). If this were a geniculate coralline, the occurrence of cell fusions would suggest an affinity with the Corallinaceae subfamily Corallinoideae. However, if it were a nongeniculate coral-

Figure 4. a-b: Lithophyllum conocristatum Maslov, 1962; a, section of the encrusting thallus bearing a uniporate conceptacle; b, detail of the conceptacle showing the conceptacle roof filaments arranged in fans oblique to the pore walls (arrow). c-d: Lithophyllum dioscurensum Maslov, 1956; c, section of the type specimen consisting of a single system of radiating and dividing cell filaments; $\mathbf{d}$, section of two multiporate conceptacles (p, pore canal) showing poorly defined long cells, probably reflecting cell elongation of conceptacle primordia (arrow). e-f: Melobesia (Lithoporella) karpatica Maslov, 1962; e, encrusting ondulated thallus with dorsiventral dimerous construction; f, detail of figure 4e. Note elongated cells connected by cell fusions (arrow). 

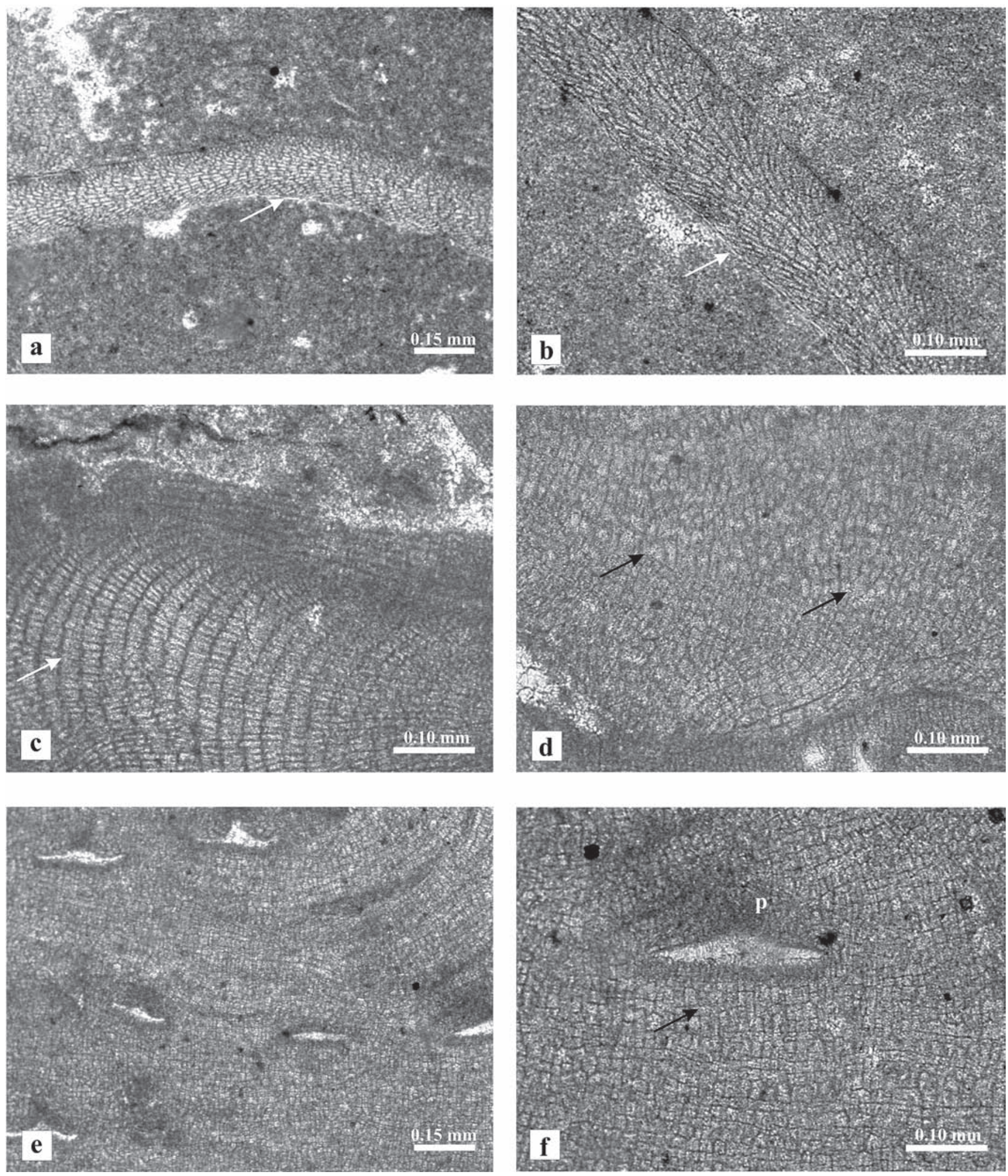

Figure 5. a-b: Lithophyllum (Tenarea?) lithothamnioides Maslov, 1962; a, contorted and branching laminar plants with bilateral growth of a single system of radiating filaments that grew and curved outwards to both sides; note the preserved epithallial cells at the tip of some filaments (arrows); b, detail showing the frequently fused cells of adjacent filaments (arrow). c, Lithophyllum pavlovii Maslov, 1956; longitudinal section of the fan-like arranged filaments with laterally well-aligned primary cell walls; note the cell fusions between adjacent filaments (arrows). d-f: Lithophyllum platticarpum Maslov, 1962; d, detail of the ventral core; $\mathbf{e}$, sections of lenticular to moustache-shaped, small, uniporate conceptacles; $\mathbf{f}$, detail of a uniporate conceptacle with a relatively large and conical pore canal (p); note the frequent cells fusions between adjacent filaments (arrows). 
line, the vegetative features would indicate a relationship with the Corallinaceae subfamily Mastophoroideae or the Hapalidiaceae subfamily Melobesioideae (Tab. 1).

\section{Lithophyllum platticarpum Maslov, 1962}

$$
\text { Figs. 5d-f }
$$

1962 Lithophyllum platticarpum Maslov, 88-89, pl. 26, figs. 1-3, text-fig. 66.

1973 Lithophyllum platicarpum Masl.; Maslov, pl. 18, fig. 10.

? 1977 Leptolithophyllum platicarpum; Orszag-Sperber, Poignant \& Poisson, 290, pl. 3, fig. 4.

? 1988 Leptolithophyllum platticarpum (Maslov) Poignant; Studencki, 45-46, pl. 15, fig. 3.

? 1989 Leptolithophyllum platticarpum (Maslov) Poignant; Pisera \& Studencki, 202, pl. 11, fig. 5.

? 1994 Lithophyllum platticarpum Maslov; Vannucci et al., pl. 1, fig. a.

Holotype: Designated by Maslov (1962, p. 88), thin section 383/8, illustrated in pl. 26, figs. 1-3 and text-fig. 66 .

Age and locality: Badenian (Tortonian in Maslov, 1962), village Ljuben Velikij, west of Lvov, western Ukraine.

Examination of the type material: The only remaining thin section contains several fragments of plants similar to the ones illustrated by Maslov (1962: pl. 26, figs. 1-3 and text-fig. 66; Fig. 1) when he established L. platticarpum. Some of the fragments are abraded and overgrown by conspecific plants (or regenerating thalli) or by other coralline algae.

The specimens named L. platticarpum consist of encrusting and dorsiventral monomerous thalli. Cell filaments run parallel to the substrate for short distances, forming a plumose ventral core (with cells 10-14 x 15-30 $\mu \mathrm{m}$ ) and then curve upwards to become perpendicular to the dorsal surface. In both the ventral core and the peripheral region, cells of adjacent filaments are strongly fused, irregular in shape and relatively large (10-15 $\mu \mathrm{m}$ in diameter and 10-20 $\mu \mathrm{m}$ in height).

Conceptacles are uniporate. Conceptacle chambers are small (210-230 $\mu \mathrm{m}$ in diameter and 35-50 $\mu \mathrm{m}$ in height) and lenticular to moustache-shaped in section. The pore canal is conical and large $(15 \mu \mathrm{m})$ in relation to the conceptacle chamber. This kind of size and shape is typical of gametangial conceptacles in species belonging to the Corallinaceae (subfamilies Mastophoroideae and Lithophylloideae, Tab. 1).

Remarks: Although the occurrence of cell fusions in the thalli and the preserved conceptacles in the holotype suggest that they are gametangial plants of the subfamily Mastophoroideae within the family Corallinaceae (Tabs. $1,2)$, the lack of sporangial conceptacles prevents the inclusion of $L$. platticarpum in a defined genus within this subfamily. The size and shape of the conceptacles were the main characters used by Maslov (1962) to distinguish L. platticarpum from coralline algae with similar vegetative characters. These features, however, cannot be compared with those of tetrasporangial plants used to delimit other species within the subfamily and, therefore, do not warrant confidently maintaining L. platticarpum as a separate species. Future studies may show that the specimens named L. platticarpum by Maslov (1962) correspond to gametangial plants of an extinct or extant mastophoroid species, characterised by features shown in sporangial and gametangial thalli, already described or as yet unnamed. The name L. platticarpum might be used in the latter case. The thalli illustrated by Orszag-Sperber et al. (1977), Studencki (1988), Pisera \& Studencki (1989) and Vanucci et al. (1994) correspond to gametangial plants of mastophoroid species. However, it cannot be confidently ascertained whether they are conspecific with the type of platticarpum due to the lack of diagnostic features used to delimit genera and species within the subfamily. Orszag-Sperber et al. (1977) transferred Lithophyllum platticarpum to the genus Leptolithophyllum Airoldi, 1930. Independently of the status of the latter genus the new combination was not validly published according to the ICBN (Art. 33.3).

\section{Lithophyllum premoluccense var. cretacicum Maslov, 1956 Figs. 6a-b}

1956 Lithophyllum premoluccense var. cretacicum Maslov, 118-119, pl. 31, fig. 2; pl. 34, fig. 6, text-fig. 49.

1962 Lithophyllum premoluccense var. cretacicum Maslov; Maslov, 90, text-fig. 68.

Holotype: Designated by Maslov (1956, p. 119), thin section $3504 / 5168$, illustrated in pl. 31 , fig. 2 ; pl. 34 , fig. 6 , and textfig. 49 .

Age and locality: Late Cretaceous, Iora river basin, Georgia.

Examination of the type material: One thin section numbered 5168 which contains the specimen described, illustrated and designated by Maslov (1956) as the holotype (Fig. 1).

The specimen is a small abraded fragment, $1 \mathrm{~mm}$ long and $0.55 \mathrm{~mm}$ wide, that may correspond to a branch of a nongeniculate plant or to an intergenicula segment of a geniculate coralline alga. The fragment consists of a single system of radiating and dividing cell filaments. Primary cell walls are laterally well aligned, generating a coaxial organisation of arched rows of cells with various lengths (ranging from 7 to $9 \mu \mathrm{m}$ in diameter and from 50 to $80 \mu \mathrm{m}$ in length). Cells in the centre of each row are longer than the ones in the periphery. Walls separating adjoining filaments are well-defined and continuous, suggesting that adjacent cells are only connected by secondary pits. The pattern of cell rows in the lower part of the fragment suggests aborted branching or abrasion leaving only the central part of a branched thallus. A poorly preserved protuberant structure on the surface of one side may correspond to the tangential section of a conceptacle, but no features indicating the nature of the possible conceptacle are recognisable.

Remarks: The absence of cell fusions in the type of $L$. premolluccense var. cretacicum indicates that it corresponds to a member of the subfamily Lithophylloideae 

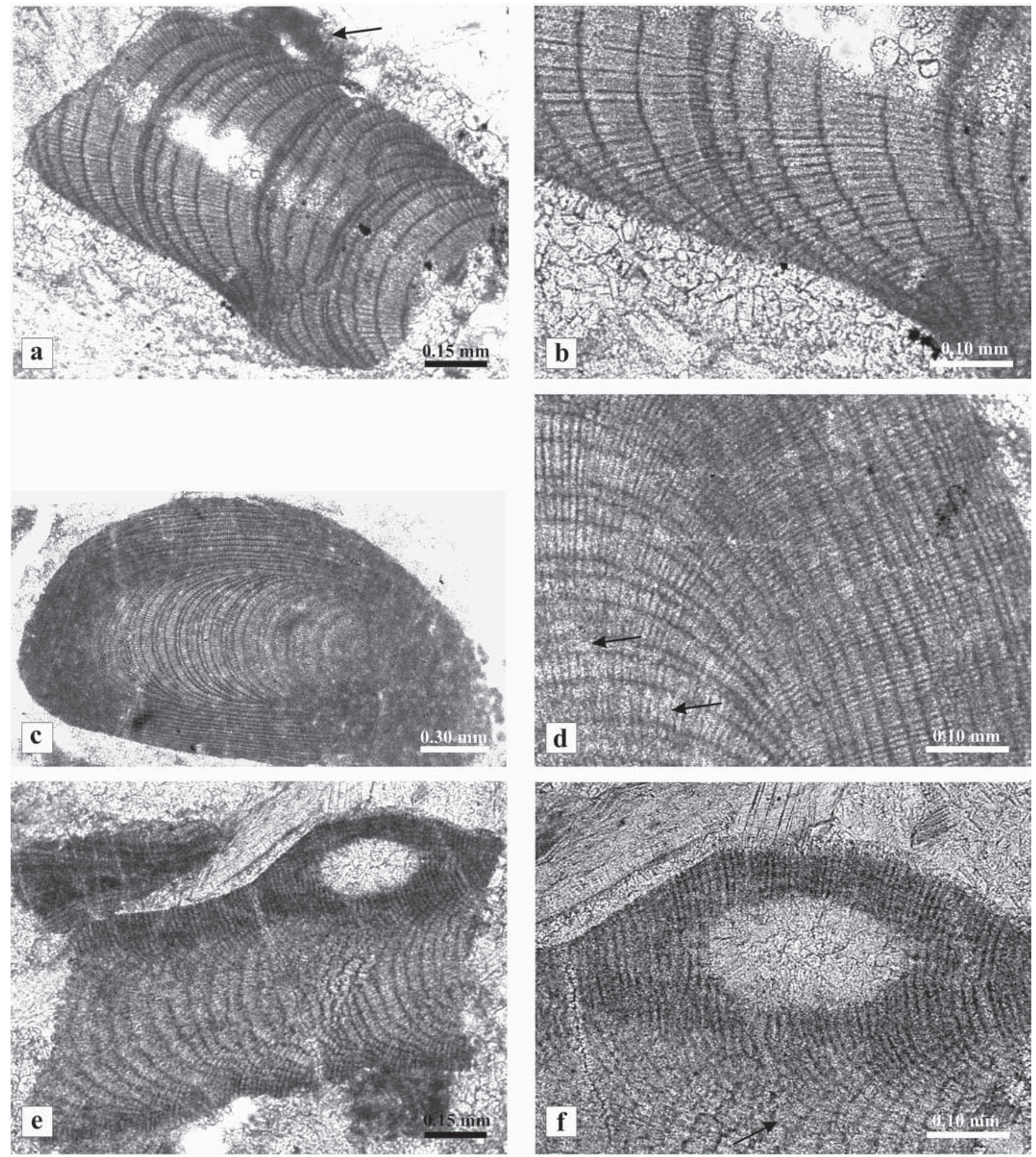

Figure 6. a-b: Lithophyllum premoluccense var. cretacicum Maslov, 1956; a, small abraded fragment consisting in a single system of radiating and dividing cell filaments with coaxial arrangement; the protuberant structure on the top surface (arrow) possibly corresponds to a tangential section of a conceptacle; $\mathbf{b}$, detail of arched rows of laterally well aligned cells in the coaxial structure. c-d: Lithophyllum senonicum Maslov, 1956; c, section of the only specimen, an abraded fragment with a core of coaxial cell filaments which curve outwards to become perpendicular to the thallus surface; d, detail of figure $6 \mathrm{c}$ showing cell fusions (arrows) and the change in cell size from the core to the periphery; e-f: Lithophyllum translucidum Maslov, 1956; e, small fragment of a monomerous plant showing the radiating and dividing cell filaments which curve outwards to become almost perpendicular to the outer surface of the thallus; $\mathbf{f}$, detail of filaments with cell fusions (arrow) and the tangential section of the conceptacle. 
in the family Corallinaceae. The lack of other significant features, however, prevents any confident assignment of L. premoluccense var. cretacicum to known genera within this subfamily (Tabs. 1, 2).

\section{Lithophyllum senonicum Maslov, 1956} Figs. 6c-d

1956 Lithophyllum senonicum Maslov, 118, pl. 34, fig. 3, textfig. 48.

1962 Lithophyllum senonicum Maslov; Maslov, 92, text-fig. 10.

Holotype: Designated by Maslov (1956, p. 118), thin section 3504/5127, illustrated in pl. 34, fig. 3, text-fig. 48.

Age and locality: Maastrichtian, Iora river basin, Georgia.

Examination of the type material: One thin section numbered 5127, which contains the specimen described and illustrated by Maslov (1956) (Fig. 1).

The specimen consists of an oblique section of a small, abraded fragment of a coralline fruticose branch $2 \mathrm{~mm}$ long and $1 \mathrm{~mm}$ wide. It may be a branch of a nongeniculate coralline alga or an intergenicula segment of a geniculate plant. The thallus shows monomerous construction with a single system of cell filaments that are coaxially arranged in rows in the core and curve outwards to become perpendicular to the thallus surface. The cells both in the core and in the peripheral region are connected by cell fusions. Cell size changes from row to row, but is always longer in the core $(8-10 \mu \mathrm{m}$ in diameter and 35-50 $\mu \mathrm{m}$ in height) than in the periphery of the thallus (7-9 $\mu \mathrm{m}$ in diameter and 20$25 \mu \mathrm{m}$ in length ). No conceptacles are present.

Remarks: The occurrence of cell fusions excludes the assignment of L. senonicum to the subfamily Lithophylloideae but the lack of other significant characters prevents its inclusion in any defined generic or suprageneric taxon within the Hapalidiaceae, or the Corallinaceae subfamily Mastophoroideae or subfamily Corallinoideae (Tabs. 1, 2).

\section{Lithophyllum translucidum Maslov, 1956} Figs. 6e-f

1956 Lithophyllum translucidum Maslov, 121-122, pl. 36, fig. 2, text-fig. 53.

1962 Lithophyllum translucidum Maslov; Maslov, 92-93, textfig. 61-62.

Holotype: Designated by Maslov (1956, p. 122), thin section 3504/5038, illustrated in pl.36, fig. 2, text-fig. 53.

Age and locality: Late Senonian, Kahetia region, Georgia.

Examination of the type material: The only remaining thin section contains the specimen illustrated by Maslov (1956) (Fig. 1). It is a small fragment (1.1 $\mathrm{mm}$ long and $0.53 \mathrm{~mm}$ thick) of a plant with monomerous construction consisting of a system of radiating and dividing cell filaments, which curve outwards to become almost perpendicular to the outer surface of the thallus. This fragment may be the remains of a branch of a nongeniculate plant or of an intergenicula segment of a geniculate coralline alga. Primary cell walls in adjacent filaments are relatively well-aligned and coaxially arranged. Cells are 9-10 $\mu \mathrm{m}$ in diameter and 40-44 $\mu \mathrm{m}$ in length. The cells of adjoining filaments are connected by cell fusions. The section tangentially cuts a conceptacle chamber on one side of the thallus, but it is unclear whether it is uni- or multiporate.

Remarks: The presence of cell fusions excludes the assignment of L. translucidum to the subfamily Lithophylloideae, but the lack of other significant characters prevents its inclusion in any defined generic or suprageneric taxon within the Hapalidiaceae, or the Corallinaceae subfamily Mastophoroideae or subfamily Corallinoideae (Tab. 1).

\section{TAXA INVOLVING MISSING TYPES}

The holotypes designated by Maslov (1956) of the following two species names were not found in the Maslov collection of in the Geological Institute of the Russian Academy of Sciences of Moscow. There are, however, thin sections containing coralline algae attributed to these species and illustrated in later works by Maslov $(1962,1973)$.

\section{Melobesia (Lithoporella) parasitica Maslov, 1956 \\ Fig. 7}

1956 Melobesia (Lithoporella) parasitica Maslov; 161-162, pl. 64, text-fig. 82.

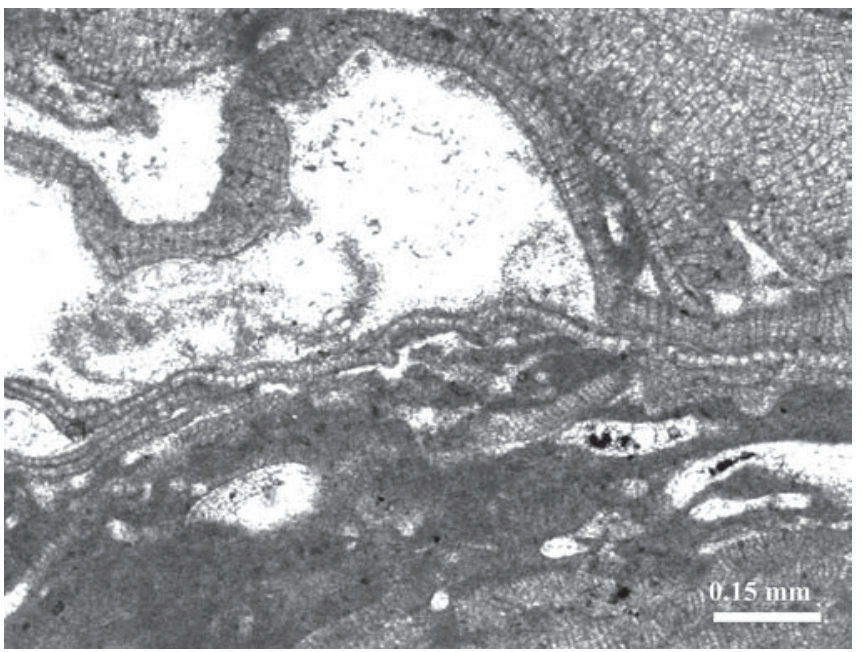

Figure 7. Melobesia (Lithoporella) parasitica Maslov, 1956; section of several superimposed, small, unistratose, encrusting plants. 
1962 Melobesia (Lithoporella) parasitica Maslov; Maslov, 100, pl. 23, figs. 1-3; pl. 27; text-fig. 79.

1973 Melobesia (Lithoporella) parasitica Masl.; Maslov, pl. 18, fig. 5 .

Holotype: Designated by Maslov (1956, p.162), thin section $3504 / 1448$, illustrated in pl. 64, and text-fig. 82.

Age and locality: Badenian (Tortonian in Maslov, 1956), western slope of Vysokaja Tura, Toltry mountains, village Gumenzy, Opol'e, Ukraine.

Examination of the collection: The only remaining thin section in the Maslov collection is the one numbered 387, which is not the holotype (Fig. 1); instead, it contains plants later illustrated by Maslov (1962, pl. 23, fig. 1). There are several superimposed, small unistratose, dimerous plants. Their cells $(10-13 \mu \mathrm{m}$ in diameter and 16-18 $\mu \mathrm{m}$ in length) seem to be joined by cell fusions. No reproductive structures are recognisable.

Remarks: The lack of significant vegetative features, together with the absence of any reproductive structures, prevents any assignment of the specimens attributed by Maslov (1962) to Melobesia (Lithoporella) parasitica to known generic taxa within the Corallinales (Tab. 2). The occurrence of cell fusions would suggest an affinity with the Corallinaceae subfamily Mastophoroideae or the Hapalidiaceae subfamily Melobesioideae. The actual nature of the "problematic conceptacle" drawn by Maslov (1956, text fig. 82a) in the protologue of the species remains uncertain since the holotype thin section was not found.

\section{Lithophyllum (Dermatolithon) ucrainicum Maslov, 1956}

Holotype: Designated by Maslov (1956, p. 159), thin section $3504 / 60$, illustrated in pl. 62, figs. 1-3 and text-fig. 80 .

Age and locality: Badenian (Tortonian in Maslov, 1956), Toltry mountains, village Gumenzy, Opol'e, western Ukraine.

Examination of Maslov's material: There are two thin sections on which the name $L$. (D.) ucrainicum is written: 350 and another not numbered. The latter is also labelled as "paratype" in the handwriting of a curator of Maslov's collection. None of them, however, is the one designated as the holotype by Maslov (1956). The plants in sample 350 were illustrated by Maslov (1962) in pl. 24, figs. 1 and 2. The remaining thin sections contain several plants and surperimposed applanate branches of one to several plants with vegetative characters similar to those illustrated among coralline plants that belong to other taxa. They are all dorsiventral and dimerous with a ventral layer of primigenous filaments of squarish to palisade cells. Short postigenous filaments, comprising up to 5 cells, may arise perpendicularly from the ventral layer. Well-defined cell walls separating adjacent filaments indicate the absence of cell fusions. Sections of uniporate conceptacles can be observed in plants in the two thin sections.
They are prominent on the thallus surface and hemispherical in shape. Conceptacle floors are situated 1 to 3 cell layers deep in the surrounding vegetative portion of the thallus.

Remarks: The vegetative and reproductive features of the plants included by Maslov (1962) in L. (D.) ucrainicum indicate that they can be assigned to Lithophyllum, in particular they reveal a strong resemblance to fossil and living plants of L. pustulatum (Lamouroux) Foslie. However, the lack of the holotype thin section and the uncertain features shown by the plants illustrated by Maslov (1956) when he established this name make it difficult to ascertain whether the plants in the remaining thin sections are conspecific with the ones in the designated type. While the specimen in pl. 62, fig. 3 (Maslov, 1956) might be a portion of a thallus similar to the plants described by the author in 1962, the vegetative characters of the plants in pl. 62, figs. 1 and 2 (Maslov, 1956) are obscure and difficult to interpret. In the absence of the designated holotype sample the circumscription of $L$. (D.) ucrainicum will remain doubtful.

\section{ACKNOWLEDGEMENTS}

This study was supported by the Grupo de Investigación RNM 190 of the Junta de Andalucía (Spain), by the Italian national research fund Cofin-Prin 2002, and by the International Inter-university Collaboration fund at the University of Ferrara (Italy). We are grateful to W.J. Woelkerling for valuable advice on nomenclature questions and very helpful review of the manuscript. We also thank REP reviewer Michael Rasser for his suggestions. We thank Christine Laurin for revising the English text.

\section{REFERENCES}

Adey, W.H. 1965. The algal tribe Lithophylleae and its included genera. Colorado School of Mines Quarterly, 60, 67-102.

Aguirre, J. \& Braga, J.C. 2005. The citation of nongeniculate fossil coralline red algal species in the twentieth century literature: an analysis with implications. Revista Española de Micropaleontología, 37, 57-62.

Aguirre, J., Braga, J.C. \& Piller, W.E. 1996. Reassessment of Palaeothamnium Conti 1946 (Corallinales, Rhodophyta). Revue of Paleobotany and Palynology, 94, 1-9.

Airoldi, M. 1930. Su di un nuovo genere di Corallinacea fossile dell'Oligocene ligure. Rendiconti Accademia Nazionale dei Lincei, Ser. 6, 12, 681-684.

Bassi, D., Woelkerling, W.J. \& Nebelsick, J.H. 2000. Taxonomic and biostratigraphical re-assessment of Subterraniphyllum Elliott (Corallinales, Rhodophyta). Palaeontology, 43, 405-425.

Bassi, D., Zakrevskaya, E. \& Fugagnoli, A. 2002. A guide to the collections of Vladimir Maslov (Rhodophyta, Cora- 
llinales). In: Research advances in calcareous algae and microbial carbonates (Eds. I. Bucur \& S. Filipescu). Proceedings of the 4th IFAA Regional Meeting, Cluj-Napoca, Aug. 29-Sept. 5, 2001, Cluj University Press, 71-81.

Bassi, D., Braga, J.C., Zakrevskaya, E. \& Petrovna Radionova, E. 2005. Re-assessment of the type collections of corallinalean genera (Corallinales, Rhodophyta) described by Maslov (1935-1962). Palaeontology, 48, 929-945

Basso, D., Fravega, P. \& Vannucci, G. 1996. Fossil and living corallinaceans related to the Mediterranean endemic species Lithophyllum racemus (Lamarck) Foslie. Facies, 35, 275-292.

Basso, D., Fravega, P., Piazza, M. \& Vannucci, G. 1998. Revision and re-documentation of M. Airoldi's species of Mesophyllum from the Tertiary Piedmont Basin (NW Italy). Rivista Italiana di Palentologia e Stratigrafia, 104, 85-94.

Bizzozero, G. 1885. Flora Veneta Crittogamica. Parte II. Seminario, Padova. i, 1, 255 pp.

Bory, J.B. 1832. Notice sur les polypiers de la Grèce. Expédition Scientifique Morée (Section Sciences Physiques), 3, 204-209.

Braga, J.C. \& Aguirre, J. 1995. Taxonomy of fossil coralline algal species: Neogene Lithophylloideae (Rhodophyta, Corallinaceae) from southern Spain. Review of Palaeobotany and Palynology, 86, 265-285.

Braga, J.C. \& Aguirre, J. 1998. Redescription of Lemoine's (1939) types of coralline algal species from Algeria. $\mathrm{Pa}$ laeontology, 41, 489-507.

Braga, J.C. \& Riding, R. 2004. Fossil Plants. Calcareous Algae. In: Encyclopedia of Geology (eds. R.C. Selley, L.R.M. Cocks \& I.R. Plimer). Elsevier, Amsterdam, 428-436.

Braga, J.C., Bosence, D.W.J. \& Steneck, R.S. 1993. New anatomical characters in fossil coralline algae and their taxonomic implications. Palaeontology, 36, 535-547.

Campbell, S.J. \& Woelkerling, W.J. 1990. Are Titanoderma and Lithophyllum (Corallinaceae, Rhodophyta) distinct genera? Phycologia, 29, 114-125.

Chamberlain, Y.M., Irvine, L.M. \& Walker, R. 1988. A redescription of Lithophyllum crouanii (Rhodophyta, Corallinales) in the British Isles with an assessment of its relationships to L. orbiculatum. British Phycological Journal, 23, 177-192.

Chamberlain, Y.M. 1991. Historical and taxonomic studies in the genus Titanoderma (Rhodophyta, Corallinales) in the British Isles. Bulletin of the British Museum of Natural History (Botany), 21, 1-80.

Decaisne, J. 1842. Essais sur une classification des algues et des polypiers calcifères de Lamouroux. Annales des Sciences Naturelles (Botanique), Sér. 2, 17, 297-381.

Foslie, M. 1909. Algologiske notiser. 6. Kongelige Norske Videnskabers Selskab Skrifter, 1909, 1-63.

Fravega, P. \& Vannucci, G. 1982. Significato e caratteristiche degli episodi a rhodoliti al "top" del Serravalliano tipo. Geologica Romana, 21, 705-715.

Fravega, P. \& Vannucci, G. 1987. Significato delle facies algali delle sequenze tardo serravalliane-tortoniane ad
Ovest di Gavi (Bacino Terziario del Piemonte). Bollettino dell'Accademia Gioenia di Scienze Naturali, 20, 317-334.

Fravega, P., Giammarino, S. \& Vannucci, G. 1984. Episodi ad "algal balls" e loro significato al passaggio Arenarie di Serravalle-Marne di S. Agata Fossili a Nord di Gavi (Bacino Terziario del Piemonte). Atti della Società Toscana di Scienze Naturali, Memorie, 91, 1-20.

Greuter, W., McNeill, J., Barrie, F.R., Burdet, H.M., Demoulin, V., Filgueiras, T.S., Nicolson, D. H., Silva, P.C., Skog, J.E., Trehane, P., Turland, N. J. \& Hawksworth, D.L. 2000. International Code of Botanical Nomenclature (St Louis Code) adopted by the Sixteenth International Botanical Congress, St Louis, Missouri, July-August 1999. Koeltz Scientific Books, Königstein, Germany, 474 pp.

Harvey, A.S., Broadwater, S.T., Woelkerling, W.J. \& Mitrovski, P.J. 2003. Choreonema (Corallinales, Rhodophyta): 18S rDNA phylogeny and resurrection of the Hapalidiaceae for the subfamilies Choreonematoideae, Austrolithoideae, and Melobesioideae. Journal of Phycology, 39, 988-998.

Krivin, A.L. \& Maslov, V.P. 1962. New data on stratigraphy and algae of Upper Cretaceous-Lower Paleocene of Marmaroshkian massif. Izvestiya Akademii nauk SSSR, Ser. Geol., 12, 61-71 (in Russian).

Kützing, F.T. 1843. Phycologia Generalis. F.A. Brockhaus, Leipzig, $458 \mathrm{pp}$.

Lamouroux, J.V.F. 1812. Extrait d'une mémoire sur la classification des polypiers coralligènes non entiérement pierreux. Nouvelle Bulletin des Sciences de la Societé de Philomatematique, 3, 181-188.

Lemoine, M.P. 1929. Contributions a l'étude des Corallinacées fossiles. X. Les Mélobésiées recuillies par M. Viennot dans la Miocène de la province de Grenade. Bulletin de la Societé géologique de France, ser. 4, 29, 263-272.

Maslov, V.P. 1956. Fossil calcareous algae of USSR. Trudy Instituta geologicheskih nauk Akademii Nauk SSSR, 160, 1-301 (in Russian).

Maslov, V.P. 1962. Fossil red algae of USSR and their connections with facies. Trudy Geologicheskogo Instituta Akademii Nauk SSSR, 53, 1-222 (in Russian).

Maslov, V.P. 1973. Atlas of rock-building organisms. Izdatelstvo Nauka, Moscow, 264 pp. (in Russian).

Mastrorilli, V.I. 1968. Nuovo contributo allo studio delle Corallinacee dell'Oligocene Ligure-Piemontese: i reperti della tavoletta Ponzone. Atti dell'Istituto di Geologia Università di Genova, 5, 153-406.

Nägeli, C., 1858. Die Staerkekoerner. Vol. 2 of Nägeli, C. \& Cramer, C., Pflanzenphysiologische Untersuchungen. Friedrich Schulthess, Zurich, 624 pp.

Orszag-Sperber, F. \& Poignant, A.F. 1972. Corallinacées du Miocène de la plaine orientale corse. Revue de Micropaléontologie, 15, 115-124.

Orszag-Sperber, F., Poignant, A.F. \& Poisson, A. 1977. Paleogeographic significance of rhodolites: some examples from the Miocene of France and Turkey. In: Fossil Algae. Recent results and developments (ed. E. Flügel). SpringerVerlag, Berlin, 286-294.

Penrose, D. \& Woelkelring, W.J. 1992. A reappraisal of 
Hydrolithon (Corallinaceae, Rhodophyta) and its relationships to Spongites. Phycologia, 21, 81-88.

Philippi, R. 1837. Beweis dass die Nulliporen Pflanzen sind. Archiv für Naturgeschichte, 3, 387-393.

Pia, J. 1927. Thallophyta. In: Handbuch der Paläobotanik, 1: Thallophyta, Bryophyta, Pteridophyta (Ed. M. Hirmer). R. Oldenbourg, München, 31-136.

Pisera, A. 1985. Palaeoecology and lithogenesis of the Middle Miocene (Badenian) algal-vermetid reefs from the Roztocze Hills, south-eastern Poland. Acta Geologica Polonica, 35, 89-155.

Pisera, A. \& Studencki, W. 1989. Middle Miocene rhodoliths from the Korytnica Basin (Southern Poland): environmental significance and paleontology. Acta Palaeontologica Polonica, 34, 179-209.

Poignant, A.F. 1971. A propos du Lithophyllum duplex Maslov. Cahiers de Géologie, 87, 1172-1174.

Rasser, M. \& Piller, W.E. 1994. Re-documentation of Paleocene coralline algae of Austria, described by Lemoine (1939). Beiträge zur Paläontologie, 19, 219-225.

Riding, R. 2004. Solenopora is a chaetetid sponge, not an alga. Palaeontology, 47, 117-122.

Setchell, W.A. 1943. Mastophora and the Mastophoreae: Genus and subfamily of Corallinaceae. Proceedings of the National Academy of Sciences U.S.A., 29, 87-97.

Silva, P.C. \& Johansen, H.W. 1986. A reappraisal of the order Corallinales (Rhodophyceae). British Phycological Journal, 21, 245-254.

Studencki, W. 1988. Red algae from the Pinczów Limestone (Middle Miocene; Swietokrzyskie Mts, Central Poland). Acta Palaeontologica Polonica, 33, 4-57.

Vannucci, G. 1980. Prime indagini sulle rodoliti del "Serravalliano" della Valle Scrivia. Quaderni dell'Istituto di Geologia della Università di Genova, 5, 59-64.

Vannucci, G., Piazza, M., Fravega, P. \& Arnera, V. 1994. Le
Rodoliti del Miocene inferiore del settore SW del Bacino Terziario del Piemonte (Spigno Monferrato - Alessandria). Atti della Società Toscana di Scienze Naturali Memorie, serie A, 100, 93-117.

Woelkerling, W.J. 1988. The coralline red algae: an analysis of the genera and subfamilies of nongeniculate Corallinaceae. Oxford University Press, London and Oxford, $268 \mathrm{pp}$.

Woelkerling, W.J. 1996. Subfamily Lithophylloideae. In: The marine benthic flora of southern Australia. Part IIIB. Gracilariales, Rhodymeniales, Corallinales and Bonnemaisoniales (Ed. H.B.S. Womersley). Australian Biological Resources Study, Canberra, 214-237.

Woelkerling, W.J. \& Campbell, S.J. 1992. An account of southern Australian species of Lithophyllum (Corallinaceae, Rhodophyta). Bulletin of the British Museum (Natural History), Botany Series, 22, 1-107.

Woelkerling, W.J., Chamberlain, Y.M. \& Silva, P.C. 1985. A taxonomic and nomenclatorial reassessment of $\mathrm{Te}$ narea, Titanoderma and Dermatolithon (Corallinaceae, Rhodophyta) based on studies of type and other critical specimens. Phycologia, 24, 317-337.

Woelkerling, W.J., Campbell, S. J. \& Harvey, A.S. 1993. Growth-forms in non-geniculate coralline red algae (Corallinales, Rhodophyta). Australian Systematic Botany, 6, 277-293.

Woelkerling, W.J., Sartoni, G. \& Boddi, s. 2002. Paulsilvella huveorum gen. \& sp. nov. (Corallinaceae, Rhodophyta) from the Holocene of Somalia and Kenya, with reassessment of Lithothrix antiqua from Late Pleistocene of Mauritius. Phycologia, 41, 358-373.

Manuscrito recibido: 29 de Noviembre, 2004 Manuscrito aceptado: 11 de Octubre, 2005 